\title{
Children's Tiger-Head Shoes in Chinese Zhongyuan Folk Art
}

\author{
Xiaojia Ding \\ Eastern International Art College \\ Zhengzhou University of Light Industry \\ Zhengzhou, Henan, China 451450
}

\begin{abstract}
Zhongyuan Tiger-Head Shoes are a symbol of Zhongyuan traditional costume. This paper discusses TigerHead Shoes' art characteristics, and then points out TigerHead Shoes' artistic expression and featured embody form, contrasts and analyzes the structural modeling and function characteristics of Tiger-Head Shoes. This paper has analyzed Tiger-Head Shoes' artistic value to satisfy the demand of excellent traditional culture in modern dress development and innovative.
\end{abstract}

Keywords-tiger-head shoes; folk art; structural modeling; function characteristics

\section{EMBODIMENT OF TIGER-HEAD SHOES IN ZHONGYUAN CULTURAL CHARACTERISTICS}

\section{A. Tiger-head Shoes form An Important Part of Zhongyuan Fork Art}

Tiger-shoes are for children and they are made by traditional Chinese fork handicraft. They evolve from warrior tiger-head boots in Han and Tang dynasties. Zhongyuan tiger-head shoes have a very long history, meantime, they are an important part of traditional Chinese fork handicraft. The head of tiger-head shoes looks like the head of a tiger, therefore they are called tiger-head shoes. As an important traditional handicraft in Zhongyuan folk, they are the conscious and unconscious art creation having both function and aesthetic appreciation, a cultural product of development of Zhongyuan in a long time and an important witness of its historical development.

\section{B. Embodiment of Tiger-head Shoes in Zhongyuan Fork Art Characteristics}

As a kind of Zhongyuan folk art, tiger-shoes certainly embody characteristics of Zhongyuan fork art.

1) Practicability. First, infants around the age of one are still learning to walk, and circumference shoe sole of tigerhead shoes is suitable for them to learn to walk; second, mothers use a part of fragmentary shell fabric at home to make shoe sole for tiger-head shoes, and another part of fabric to decorate the head of shoes, embodying Chinese women's fine tradition of frugality in household management; last but not least, since it is very cold in Zhongyuan's winter and infant's cotton-padded trousers include package of foot, displaying big feet, therefore too small shoes not only restrict normal growth of infant's feet, but also make it difficult to put shoes on for children.

2 ) Artistry. Zhongyuan fork art mainly displays ever changing modeling decoration and plain and natural aesthetic style. Cross-stitch and mending embroidery is a big category of drawnwork and it comes down in one continuous line with Chinese traditional embroidery. Primarily, cross-stitch is a kind of stitch in embroidery. Mending originates from "silk pile", a kind of handiwork made of silk. Collage of this kind of handiwork into flowers or figures is called mending. Tiger-head shoes in Zhongyuan folk use the folk handicraft of cross-stitch and mending embroidery to make ever changing modeling and decoration of tiger-head shoes. On the basis of inheriting ancient embroidery stitches, start from aesthetic appreciation of plainness and naturalness in the process of actual design and change silk material into manifold cotton cloth, linen, cotton thread to make tiger-head shoes. ${ }^{[1]}$

3) Symbolism. Zhongyuan folk art uses certain art symbols to express symbolism. ${ }^{[2]}$ One art symbol is color. Tiger-head shoes usually use strong color contrast, like red, green, black, white, blue and so on. Each color is thick and heavy, expressing strong sight impact. Another art symbol is modeling. Zhongyuan tiger-head shoes are brutal, bold and unconstrained in configuration of main part, but they are delicate and exquisite in detailed parts. This art symbol symbolizes Zhongyuan people's crude and refined character.

\section{TIGER-HEAD SHOES' ARTISTIC EXPRESSION AND FEATURED EMBODY FORM}

Zhongyuan tiger-head shoes have unique artistic expression technique and features, which are mainly manifested in the five aspects of symmetry, exaggeration, decorativeness, comparability and randomness. Culture connotation of unique and characteristic Zhongyuan folk art is displayed through artistic expression form of tiger-head shoes. ${ }^{[3]}$ Please refer to Table I: Tiger-Head Shoes' artistic expression and featured embody form. 
TABLE I. TIGER-HEAD SHOES’ ARTISTIC EXPRESSION AND FEATURED EMBOdy Form

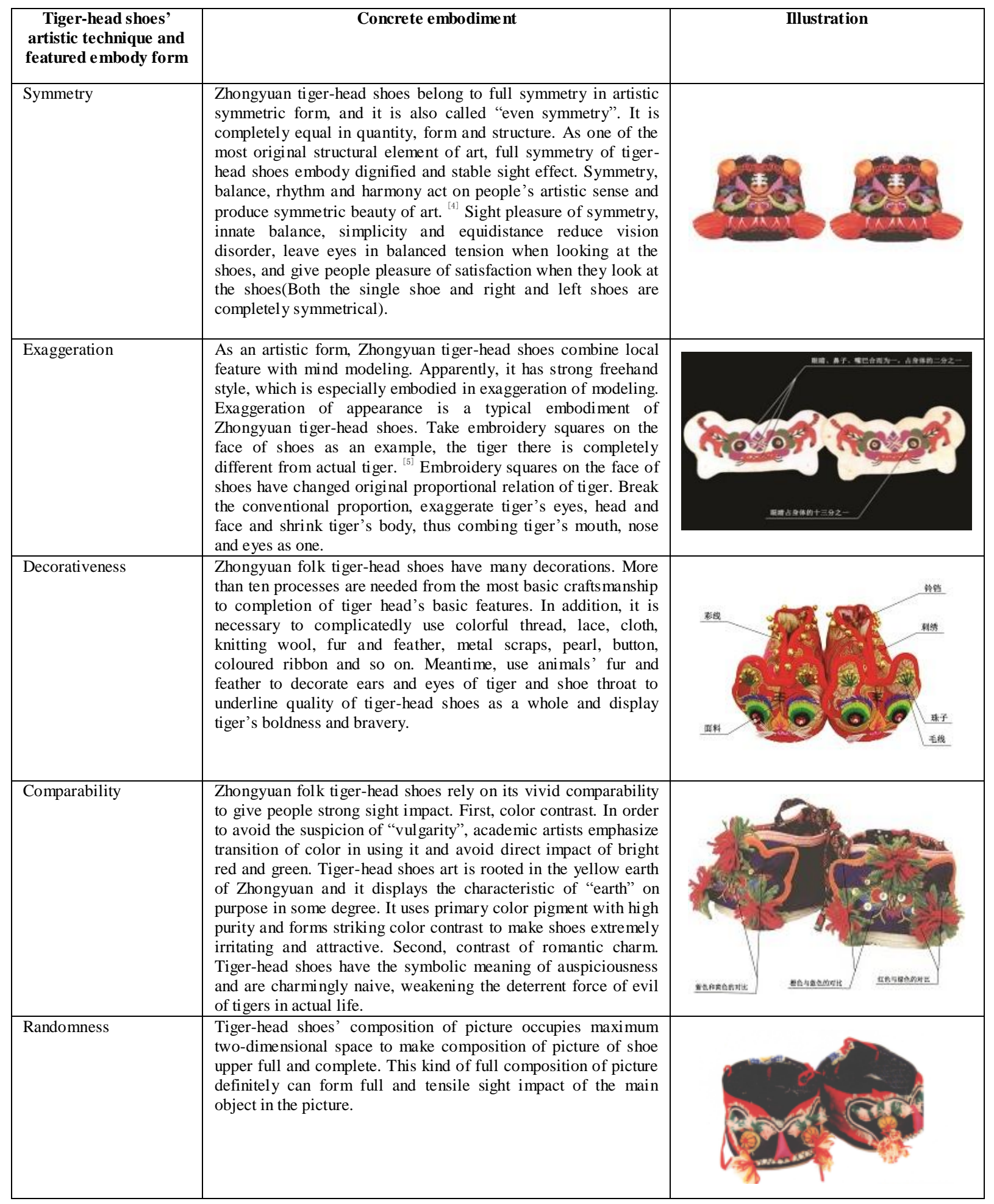

\section{STRUCTURAL MODELING AND FUNCTIONAL FEATURES OF TIGER-HEAD SHOES}

Tiger-head shoes' special structural modeling and their function are closely related. The most typical structural modeling is displayed in the three aspects of multi-layer soles, special structure of shoe warp and animal form modeling. It is exactly the three typical structural modelings that give play to functions of tiger-head shoes greatly, making tiger-head shoes still be used and loved by many people. 


\section{A. Structural Modeling and Functional Features of Tiger- Head Shoes' Multi-Layer Soles}

Tiger-head shoes' soles are made of cloth by hand. Handmade cloth sole firstly appears in Zhou Dynasty. After more than two thousand years' development, handmade cloth sole has won fame as "multi-layer sole" both at home and abroad. Handmade cloth soles have the advantage of protection against the cold in winter and heat dissipation in summer. Children's feet are still growing and they are very soft and tender. They need to keep warm in winter and dissipate heat in summer to guard against fungal infection. Besides, children are restless, so their shoes must be soft and convenient for running. ${ }^{[6]}$ Tiger-head shoes' sole has the characteristics of wear resistance, protection against cold, heat dissipation, comfort etc., thus they are suitable for healthy growth of children's feet and are loved by Zhongyuan people in a long time. Please refer to "Table II" . The comparison between children and adult's foot coefficient

TABLE II. THE COMPARISON BETWEEN CHILDREN AND AdULT'S FoOT COEFFICIENT UNIT: \%

\begin{tabular}{|c|c|c|c|}
\hline $\begin{array}{c}\text { Comparison } \\
\text { part }\end{array}$ & Children & Adults & Changing rule \\
\hline $\begin{array}{l}\text { Endpoint of } \\
\text { little toe }\end{array}$ & 84.50 & 83.73 & $\begin{array}{l}\text { The fifth toe of children is a } \\
\text { little longer and toes are } \\
\text { parallel and level }\end{array}$ \\
\hline $\begin{array}{l}\text { The first } \\
\text { plantar toe }\end{array}$ & 73.27 & 72.17 & $\begin{array}{l}\text { Hallex gradually becomes } \\
\text { longer and forefoot becomes } \\
\text { bigger }\end{array}$ \\
\hline $\begin{array}{l}\text { The fifth } \\
\text { plantar toe }\end{array}$ & 63.75 & 63.02 & $\begin{array}{l}\text { Forefoot gradually becomes } \\
\text { bigger }\end{array}$ \\
\hline $\begin{array}{l}\text { Girth of } \\
\text { former } \\
\text { supernumerar } \\
\text { y bone }\end{array}$ & 101.37 & 100.29 & $\begin{array}{l}\text { Children's supernumerary } \\
\text { girth is a little longer than } \\
\text { that of adults }\end{array}$ \\
\hline $\begin{array}{l}\text { Girth of foot } \\
\text { pocket }\end{array}$ & 128.47 & 132.00 & $\begin{array}{l}\text { Children basically have no } \\
\text { heels }\end{array}$ \\
\hline $\begin{array}{l}\text { Slanting } \\
\text { width of } \\
\text { plantar toe }\end{array}$ & 40.65 & 41.65 & $\begin{array}{l}\text { Slanting width of plantar toe } \\
\text { increases gradually }\end{array}$ \\
\hline $\begin{array}{l}\text { Width of heel } \\
\text { heart }\end{array}$ & 70.21 & 68.20 & $\begin{array}{l}\text { Children's width of heel } \\
\text { heart is longer than that of } \\
\text { adults }\end{array}$ \\
\hline $\begin{array}{l}\text { Height of the } \\
\text { first plantar } \\
\text { toe }\end{array}$ & 14.62 & 13.62 & $\begin{array}{l}\text { Gradually reduce(no evident } \\
\text { change) }\end{array}$ \\
\hline $\begin{array}{l}\text { Height of } \\
\text { hallex }\end{array}$ & 8.22 & 7.95 & Slight change \\
\hline $\begin{array}{l}\text { Height of } \\
\text { former } \\
\text { supernumerar } \\
\text { y bone }\end{array}$ & 24.27 & 23.95 & $\begin{array}{l}\text { Children's supernumerary } \\
\text { bone is higher than that of } \\
\text { adults }\end{array}$ \\
\hline $\begin{array}{l}\text { Height of } \\
\text { external } \\
\text { ankle bone }\end{array}$ & 18.84 & 19.60 & $\begin{array}{l}\text { External ankle bone } \\
\text { constantly becomes higher }\end{array}$ \\
\hline
\end{tabular}

Seeing from "Table II", the comparison between children and adult's foot coefficient, we can know that there are great changes in growing from children's foot into adults', and there is a certain change rule. From foot of children to adults, great changes have taken place in endpoint of little toe, the first plantar toe, the fifth plantar toe, girth of foot pocket, slanting width of plantar toe, width of heel heart, height of former supernumerary bone and height of external ankle bone. These parts become prominent features of children's foot: parallel and level toes, big forefoot, long supernumerary girth, no heels, and since children have more fat, their width of heel heart is longer than that of adults. ${ }^{[7-8]}$ According to change rule of foot growing from children to adults, in order to make foot grow normally from children to adults, it is necessary to consider features of children's foot in designing shoes. Tiger-head shoes' structural design of each part exactly conforms to the change rule, satisfies modeling of children's foot and gives play to their functional features.

\section{B. Structural Modeling and Functional Features of Tiger- Head Shoes' Shoe Warp}

The most typical feature of ancient Chinese shoes is that their tip upwarps. Since the pre-Qin period, tiger-head shoes have been using this kind of structural modeling to give play to important functions. Function of tiger-head shoes' tip can be concluded in the following four aspects: ${ }^{[6]}$

- When they first learn to walk, children like to straightly look at the front direction. Tiger-head shoes' tip can let children sense the existence of barrier, thus the tip can make children keep alert and reduce frequency of falling down.

- Generally speaking, shoe tip is connected to sole. Fastness of sole is far greater than that of shoe surface, thus prolonging life of shoes.

- Upwarping of shoe warp corresponds to ancient traditional belief. It is like upturned eaves of ancient buildings and has the meaning of respecting and worshiping the god.

\section{Structural Modeling and Functional Feature of Tiger- Head Shoes in the Shape of Animals}

- Children are usually rash in walking, so it is easy to kick out shoe head. Mothers cut cloth or fur into different kinds of animal pictures and add them to shoe head and shoe upper, thus increasing children's shoes' abrasive resistance and interestingness of shoes at the same time.

- It also displays traditional Chinese's totemism by adding animal pictures of tigers and so on to children's shoes.

- Making children's shoes in the shape of various kinds of animals is also out of children's mental need. Animal like shoes satisfy children's nature of enjoying bright and fancy color and embody deep mother love through clever hands and complicated knitting at the same time. 
TABLE III.

TIGER-HEAD SHOESELEMENTS' PERFORMANCE PRACTICES IN COSTUME DESIGN

\begin{tabular}{|c|c|c|}
\hline $\begin{array}{c}\text { Design } \\
\text { element }\end{array}$ & Design performance & Illustration \\
\hline Modeling & $\begin{array}{l}\text { Adopt tiger-head shoes' modeling as main content of profile } \\
\text { design of costume. Costume profile extends on the basis of } \\
\text { tiger-head shoes' modeling. Design innovation of costume is } \\
\text { conducted according to tiger-head shoes' modeling features } \\
\text { and typical features and by combining today's analysis of } \\
\text { costume profile's trend. }\end{array}$ & \\
\hline Color & $\begin{array}{l}\text { Tiger-head shoes have abundant colors which combine use of } \\
\text { bright color, high and low purity and brightness. Tiger-head } \\
\text { shoes' color is loved by many designers. }\end{array}$ & \\
\hline $\begin{array}{l}\text { Craft } \\
\text { realization }\end{array}$ & $\begin{array}{l}\text { Tiger-head shoes have complicated craftsmanship. In today's } \\
\text { costume design, the four most used crafts in costume design } \\
\text { are playing Gebei performance practice, embroidery craft and } \\
\text { seed embroidery craft. Designers use these practices and } \\
\text { unique innovative ideas to show new design ideas and design } \\
\text { works. }\end{array}$ & \\
\hline
\end{tabular}

\section{INNOVATIVE APPLICATION OF ZHONGYUAN TIGER- HEAD SHOES' ELEMENT IN TODAY'S SOCIAL FIELD}

\section{A. Application of Tiger-Head Shoes' Element in Children's Toys Field}

In our daily life, we can frequently see baby walking chair and tiger-head small bell which take tiger-head shoes' element as the theme. One of their most obvious features is that there is a big character of "king" in the middle of tiger head. They still adopt main color of tiger-head shoes to pass "tiger's" silly appearance and cute feature to children's childhood, like black, yellow, red etc.

\section{B. Application of Tiger-Head Shoes' Element in Costume Design}

From embroidery (Kaifeng embroidery), cross-stitch work, seed embroidery to craft method of more than ten procedures, every detail is the concerned object of costume designers. Please refer to Table III. Tiger-Head Shoes elements' performance practices in costume design. ${ }^{[9]}$

\section{Application of Tiger-head Shoes' Element in Home Decoration Artware}

Currently home decoration artware is mainly divided into the two categories of pure modern style and ancient-modern style. Development of ancient-modern home decoration artware pushes forward continuous innovation of Chinese classic element. Artware design with innovation of Zhongyuan tiger-head shoes' element still is loved by many people. Tigershaped pillow and tiger-shaped earthenware are very like modeling of tiger-head shoes in spirit. People are using another way to express their respect for tiger-head shoes' auspicious meaning. It is the unique way to beautify life for people and displays tiger-head shoes' art value.

\section{CONCLUSION}

Discussion of tiger-head shoes' art value has great importance on inheritance of Chinese civilization. The paper analyzes tiger-head shoes' art performance practice, feature embodiment, structural modeling and function, four aspects in total; it also combines innovative application potential of tigerhead shoes' element in children's toy field, costume field, home decoration artware field and so on. It provides basis for designers' design of children's shoes, ${ }^{[10]}$ and excavates huge application value of tiger-head shoes' element in future society.

\section{REFERENCES}

[1] Dang Chunzhi. Central Plains Folk Arts and crafts[M].Zhengzhou: Henan people's Publishing House, 2006:4.

[2] (6) :50-56.Yue Hai-ying, Wang Zhi-hong, JIANG Li. Chinese Traditional Shoes for Children [J].Journal of Xing tai Polytechnic College, 2009,26 (6):50-56.

[3] Zhang Yi. Application of auspicious patterns in traditional Chinese folk costumes [J].Journal of Textile Research, 2013,34 (5): 107-110.

[4] Xu Wei. Artistic Research of Embroidered Guanzhong Folk TigerHead Shoes [J].Journal of Xianyang Normal University, 2014,29 (1) :75-78

[5] Wang Fenling.Lu Min. Chinese tiger culture[M]. Beijing:Zhonghua Book Company, 2007:1.

[6] Luo Chong-qi. The study and appreciation in the past dynasties China shoes[M].Shanghai: Donghua University press, 2007:9.

[7] Lu Min. Modern dress series Shoe[M].Beijing:Textile Industry Press, 1991:5. 